Received: 9 January 2018

Accepted: 21 March 2018

Published online: 04 April 2018

\section{Adsorption and protective behavior of BTAH on the initial atmospheric corrosion process of copper under thin film of chloride solutions}

\author{
Chenxi Yi ${ }^{1}$, Benfeng Zhu ${ }^{1}$, Yu Chen ${ }^{2}$, Xiaoqing Du ${ }^{1}$, Yumeng Yang ${ }^{1}$, Jiao Liu ${ }^{3}$ \& Zhao Zhang ${ }^{1}$
}

The initial corrosion process of copper and the corrosion resistance mechanism of Benzotriazole under chloride-containing thin electrolyte layer (TEL) was investigated. After theoretical calculation and experimental characterization, the forming process of $[\mathrm{Cu}(\mathrm{I}) \mathrm{BTA}]_{n}$ film was chemically adsorbed on copper surface by $\mathrm{Cu}-\mathrm{N}$ bond tightly; corrosion rate increased as TEL thickness decreased. Whilst, energy distribution plot of electrochemical noise provided the validity of corrosion type, and the purported corrosion energy $\left(E_{\mathrm{c}}\right)$ deduced from electrochemical noise was approximately proportion to corrosion rate $\left(1 / R_{\mathrm{ct}}\right)$ with and without the anticorrosion film, which denoted the feasibility to determine corrosion rate by nondestructive on-line monitoring electrochemical noise progress.

As architectural materials, copper and its alloys have been widely used in marine industry due to its excellent performance ${ }^{1,2}$. However, it still suffers from serious damage during its long time serving processes, especially in marine environments ${ }^{3,4}$.

The predominant ion in seawater is $\mathrm{Cl}^{-}$, which is well known for stimulation of metal corrosion. The corrosion mechanism of copper influenced by chloride have been discussed by many researchers ${ }^{3,5}$. According to the critical review by Kear and his coworkers ${ }^{6}$, the anodic reaction mechanisms during copper corrosion in the presence of chloride ions is ${ }^{7-9}$ :

$$
\mathrm{Cu}+\mathrm{Cl}^{-} \underset{k_{-1}}{\stackrel{k_{1}}{\rightarrow}} \mathrm{CuCl}+e^{-}
$$

while, the cathodic reaction is as follows ${ }^{10}$ :

$$
\frac{1}{4} \mathrm{O}_{2}+\frac{1}{2} \mathrm{H}_{2} \mathrm{O}+e^{-} \stackrel{k_{2}}{\rightarrow} \mathrm{OH}^{-}
$$

For the initial corrosion process of copper, the main corrosion product is $\mathrm{Cu}_{2} \mathrm{O}^{11,12}$ via:

$$
\mathrm{CuCl}+\mathrm{OH}^{-} \stackrel{k_{3}}{\rightarrow} \frac{1}{2} \mathrm{Cu}_{2} \mathrm{O}+\frac{1}{2} \mathrm{H}_{2} \mathrm{O}+\mathrm{Cl}^{-}
$$

Benzotriazole (BTAH), one of the most efficient inhibitors for copper, is the most highly stressed subject of numerous scientific studies ${ }^{13-16}$, and its possible inhibition mechanism has also been proposed: the formation of an adsorption layer of $\mathrm{BTAH}^{17,18}$ or a complex polymeric film of $[\mathrm{Cu}(\mathrm{I}) \mathrm{BTA}]_{\mathrm{n}}{ }^{19-21}$ on copper surface via reaction ${ }^{22}$,

$$
\mathrm{n}(\mathrm{BTAH})_{\mathrm{ads}}+\mathrm{nCuCl} \rightarrow[\mathrm{Cu}(\mathrm{I}) \mathrm{BTA}]_{\mathrm{n}}+\mathrm{nH}^{+}+\mathrm{nCl}^{-}
$$

Metal corrosion behavior in atmospheric environments is significantly different from that in bulk solutions $s^{10,23-25}$. Atmospheric corrosion is an electrochemical process occurring on a metal surface covered with a thin electrolyte layer (TEL). TEL thickness markedly affects the corrosion-related processes, such as the mass

${ }^{1}$ Department of Chemistry, Zhejiang University, Hangzhou, Zhejiang, 310027, China. ${ }^{2}$ Department of Chemical Engineering and Safety, Binzhou University, Binzhou, Shandong, 256600, China. ${ }^{3}$ College of Chemistry and Chemical Engineering, Hunan University, Changsha, 410082, China. Correspondence and requests for materials should be addressed to Z.Z. (email: eaglezzy@zju.edu.cn) 
transport of the dissolved oxygen and the accumulation of corrosion products ${ }^{26,27}$. Yi et al. ${ }^{27}$ studied the atmospheric corrosion behavior of PCB-ENIG under the adsorbed thin electrolyte layer and found that the cathodic current density in the solution was greater than that under TEL, and decreased with the thinning of TEL film. Moreover, the controlling step of the oxygen reduction process transferred from the cathodic to the anodic process in the extremely thin liquid film.

Nowadays, a wide variety of electrochemical measurements coupled with surface analytical ${ }^{28}$ and spectroscopic techniques ${ }^{29}$ have been adopted to study the metal corrosion processes. However, it is hard to detect the corrosion in-situ and non-destructive simultaneously. Corrosion processes are associated with electrochemical metal dissolution, involving charge transfer that generate spontaneous fluctuations in current and potential. These fluctuations are defined as electrochemical noise (EN), whose measurements have received considerable attentions ${ }^{30-32}$. EN has been regarded as a powerful electrochemical technique and has been successfully utilized to investigate the corrosion process ${ }^{33-35}$ and electrodeposition process ${ }^{36}$. The prime attraction of EN technique in corrosion study is its in-situ monitoring the early initiation corrosion process with high sensitivity and no damage, whereas the traditional techniques (such as the polarization tests and the electrochemical impedance spectroscopy, etc.) often cause unexpected damage by introducing the external perturbation into the investigated electrochemical system, and may provide the corrosion information with some possible artifacts.

The frequency contribution of each EN individual transient leaves a specific signature, or "fingerprint" that can provide information on the nature of the related corrosion process ${ }^{36-39}$. Fast Wavelet Transformation technique, as a kind of discrete wavelet transform, describes the EN curves at several time-scale in so-called crystals, and the relative energy contribution from each crystal can be visualized in an energy distribution plot (EDP) ${ }^{36}$. By using the so-called RP-EDP (the replotted energy distribution plot), which discounts the contribution of smooth coefficient set from the overall ensemble signal energy, some researches took an insight into the relationship between the position of the maximum relative energy and the dominant process in certain corrosion events ${ }^{40}$, and found that EDP can provide the useful information about the transformation of the typic corrosion type of $\mathrm{Al}$ in $\mathrm{NaCl}$ solutions ${ }^{41}$ and AISI 1020 steel corrosion in seawater ${ }^{42}$ during their corrosion processes. However, the quantitative or even the semiquantitative information about the corrosion process (especially the corrosion severity) from the viewpoint of noise energy has not been reported.

The aim of this paper is to investigate the inhibition behavior of well-known BTAH on Cu mainly using electrochemical impedance spectroscopy (EIS) and EN techniques, especially to quantitatively probe into the relationship between the corrosion severity of $\mathrm{Cu}$ and its corresponding corroding noise energy. Meanwhile, the corrosion mechanism of $\mathrm{Cu}$ in the investigated corroding conditions was verified from the EIS theoretical calculations. These yields should increase the discrimination ability between the corrosion sensitivity and the electrochemical noise energy.

\section{Methods}

Materials. The corrosion process of pure copper in $3.5 \mathrm{wt} . \% \mathrm{NaCl}$ electrolyte was studied. The working electrode was mechanically cut and embedded into Teflon, leaving an exposed area of $0.5 \mathrm{~cm}^{2}$ as working surface. Prior to each experiment, the samples were abraded gradually using sand paper from 400 to 1200 grit, polished with $2.5 \mu \mathrm{m}$ diamond paste. Subsequently, the surface was rinsed with distilled water by ultrasonic cleaner about 3 min (KQ5200B, Youyi instrument Co., Ltd., China), degreased with acetone, and finally dried in a cool $\mathrm{N}_{2}$ flow.

$[\mathrm{Cu}(\mathrm{I}) \mathrm{BTA}]_{\mathrm{n}}$ film on $\mathrm{Cu}$ was fabricated as follows ${ }^{15,16}$ : the copper electrode was pre-immersed into the solution containing $0.1 \mathrm{mM} \mathrm{BTAH}$ and $4.0 \mathrm{M} \mathrm{NaCl}$ at $60^{\circ} \mathrm{C}$ for 3 hours, then ultrasonic cleaned using distilled water twice to eliminate the obstruction caused by the absorption of BTAH molecule layer, and finally drying in cool $\mathrm{N}_{2}$ flow again. In this way, the copper substrate would be covered by a thin layer of $[\mathrm{Cu}(\mathrm{I}) \mathrm{BTA}]_{\mathrm{n}}$ film. Hereinafter, the copper electrode covered with $[\mathrm{Cu}(\mathrm{I}) \mathrm{BTA}]_{\mathrm{n}}$ film is designated as $\mathrm{CuBTA}$, while those without BTAH pretreatment is simply named as $\mathrm{Cu}$.

After that, $\mathrm{CuBTA}$ and $\mathrm{Cu}$ were fixed under a layer of thin electrolyte containing $3.5 \mathrm{wt} . \% \mathrm{NaCl}$, and all the measurements were performed at the temperature of $20 \pm 1^{\circ} \mathrm{C}$.

Thin electrolyte layer set-up. The schematic diagram of TEL is president in Fig. 1. The working electrode was firmly installed in the cell, leaving only the upper surface exposed. A platinum wire $(0.5 \mathrm{~mm}$ diameter $)$ was fixed around the working electrode and positioned below the exposed surface and served as the counter electrode. A saturated calomel electrode (SCE) connected with salt bridge was inserted into the bulk solution and used as the reference electrode. The electrochemical cell, which was placed on a horizontal stage in constant humidity chamber, was adjusted to the horizontal level using a water level.

The TEL thickness was determined by equipment consisting of a sharp Pt needle and an iron support with a micrometer, as shown in Fig. 1a. The TEL thickness was determined by equipment consisting of a sharp Pt needle and an iron support with a micrometer. The first value on the micrometer was recorded at once when the Pt needle touched the electrode surface. After infusing $\mathrm{NaCl}$ solution into the cell, the second value was recorded when the Pt needle touched the electrolyte surface.

A constant humidity chamber with an electrochemical cell was completely covered with a lid (Fig. 1b) and a $\mathrm{NaCl}$ solution of the same concentration as the test solution was placed at the bottom of the chamber to maintain the stability of the TEL thickness for long immersion times during the electrochemical measurements.

Electrochemical measurements. Electrochemical measurements were conducted on an electrochemical workstation (CHI630 CH Instruments, Inc.) and all potentials were reported with respect to SCE. Tafel curve tests under various TEL thickness were conducted with a sweep rate of $1 \mathrm{mV} / \mathrm{s}$. For the linear polarization measurements, a sweep range of -5 to $+5 \mathrm{mV}$ vs. OCP (open circuit potential) at a sweep rate of $1 \mathrm{mV} / \mathrm{s}$ was used, and the polarization resistance $\left(R_{\mathrm{p}}\right)$ was determined from the slope of $E$ vs. $i$ curve in the vicinity region of the corrosion 
(a)

(b)

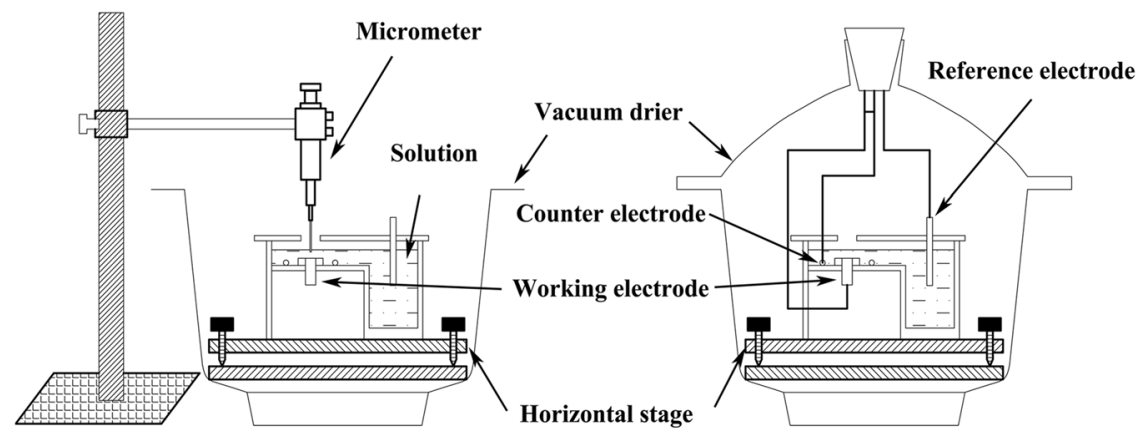

Figure 1. Schematic diagram for (a) determination of TEL thickness and (b) electrochemical measurement in corrosion study. The electrochemical cell, which was placed on a horizontal stage in constant humidity chamber, was adjusted to the horizontal level using a water level.

potential. EIS measurements were conducted in the $100 \mathrm{kHz}$ to $10 \mathrm{mHz}$ frequency range at the OCP with $\pm 5 \mathrm{mV}$ potential perturbation. The component values of EIS equivalent circuit were calculated using Z-view 3.1 software.

EN was in-situ recorded using GP Amp analyzer (A D Instruments Pty Ltd., Australia). The interval sample time was 0.25 second, by which most usual corrosion processes can be detected. The frequency window of the observation can be calculated roughly by ${ }^{43}$ :

$$
\left(C_{1}^{l}, C_{2}^{l}\right)=\left(2^{l} \Delta t, 2^{l-1} \Delta t\right)
$$

Where $l$ is the number of the crystal, and $\Delta t$ is the sampling interval of $0.25 \mathrm{~s}$. During the EN measurements, the experimental device was shielded in a Faradaic cage. The EN measurements were performed in a quiescent solution at $20 \pm 1{ }^{\circ} \mathrm{C}$ without stirring, which was also controlled by a thermostatically water bath. The Spectra were graphed using Origin 8.0 (OriginLab, Northampton, MA), and the energy values were calculated by Matlab R2014b software (The MathWorks, Inc.).

XPS imaging. X-ray photoelectron spectroscopy (XPS) analyses were performed on a VG ESCALAB MARK II spectrometer with the $\mathrm{Mg} \mathrm{K \alpha}$ radiation $(1253.6 \mathrm{eV})$, operating at constant pass energy mode at $50 \mathrm{eV}$. The surface charging effect was corrected by fixing the $\mathrm{C} 1 \mathrm{~s}$ peak at a binding energy of $284.6 \mathrm{eV}$. The constitution of each peak was processed using XPSPEAK Version 4.0 software.

FTIR spectroscopy. FTIR were recorded with a Nexus 670 (Nicolet) FT-IR spectrometer. 32 scans were performed for each spectrum with a resolution of $2 \mathrm{~cm}^{-1}$.

SEM. SEM (EDS) were performed by a SU-8010 Scanning Electron Microscope (Hitachi) coupled with an Oxford X-Max ${ }^{\mathrm{N}} 50 \mathrm{~mm}^{2}$ detector, using the low vacuum mode and the accelerating voltage of $15.0 \mathrm{kV}$.

Data availability. The datasets generated during the current study are available from the corresponding author on reasonable request.

\section{Results and Discussion}

Characterization of BTAH adsorption film. The surface coverage degree $\left(\theta_{3}\right)$ of BTAH on copper could be obtained by weight loss measurement:

$$
\theta_{3}=\frac{\Delta m_{0}-\Delta m_{1}}{\Delta m_{0}}
$$

where $\Delta m_{0}$ and $\Delta m_{1}$ are the mass loss in the absence and presence of the BTAH. Figure 2 shows the relationship between BTAH concentration and surface coverage. For BTAH, the plot of $\theta_{3}$ against logarithm of inhibitor concentration gives straight line, which is the characteristics of the Temkin adsorption isotherm given by ${ }^{44,45}$ :

$$
\exp (-2 \alpha \theta)=\mathrm{K}_{0} \mathrm{c}
$$

where $\alpha$ is the molecular interaction parameter, $\theta$ is the surface coverage degree, $\mathrm{c}$ is the inhibitor concentration in the solution, $\mathrm{K}_{0}$ is the equilibrium constant of the adsorption process which is related to the standard free energy $\Delta G_{a d s}^{0}$ of adsorption,

$$
\mathrm{K}=\frac{1}{55.5} \exp \left(-\frac{\Delta G_{a d s}^{0}}{R T}\right)
$$




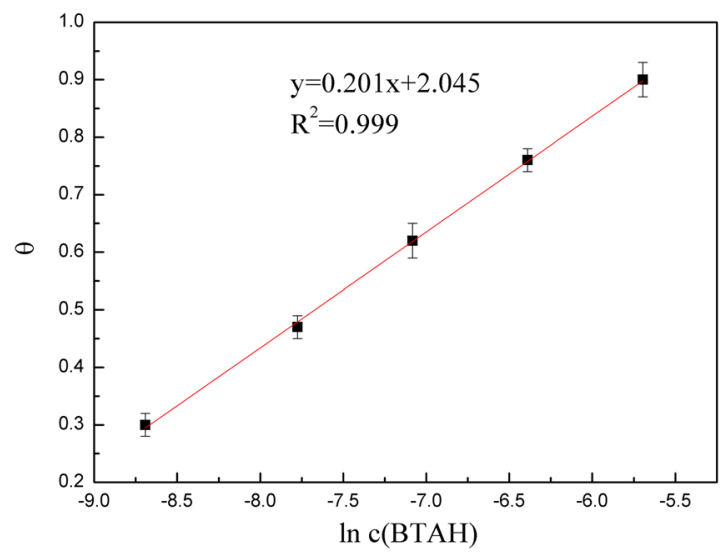

Figure 2. Temkin adsorption isotherm plots for BTAH adsorption on $\mathrm{Cu}$ in the solution containing $4.0 \mathrm{M} \mathrm{NaCl}$ at $60^{\circ} \mathrm{C}$. The fitting line is listed and $\mathrm{R}^{2}$ equals to 0.999 .
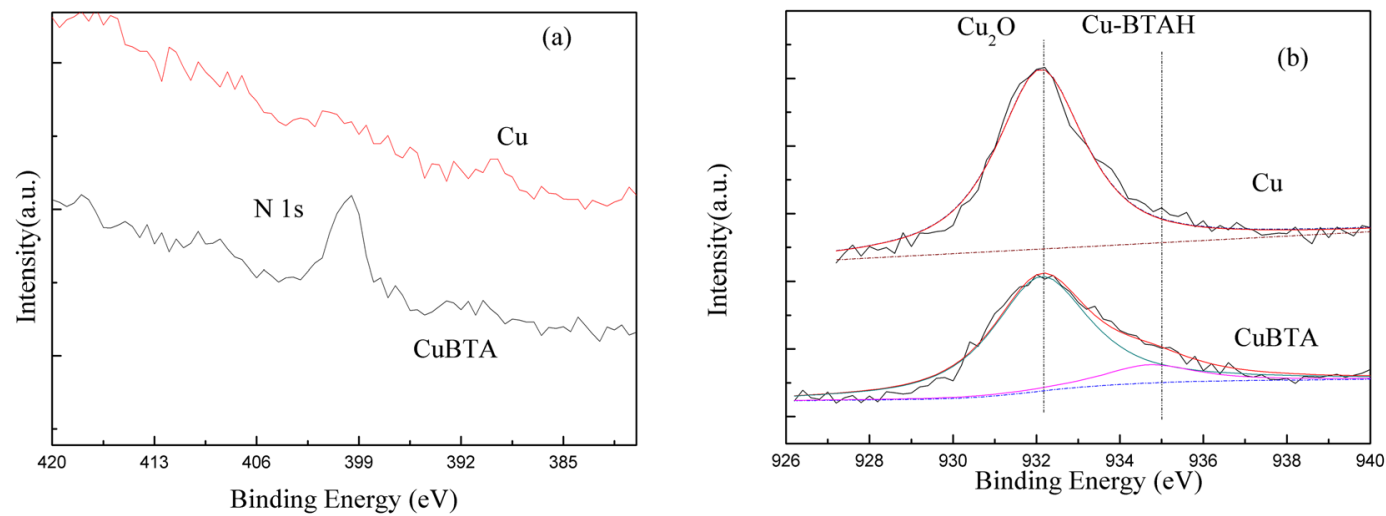

Figure 3. The XPS spectra of CuBTA and Cu after 100 min's corrosion in 3.5 wt. $\% \mathrm{NaCl}$ : (a) N $1 \mathrm{~s}$ and (b) $\mathrm{Cu}$ $2 \mathrm{p}_{3 / 2}$. The N1s peak at a binding energy of $399.6 \mathrm{eV}$ and the $\mathrm{Cu} 2 \mathrm{p}$ peak at $932.2 \mathrm{eV}$, and the surface charging effect was corrected by fixing the $\mathrm{C} 1 \mathrm{~s}$ peak at a binding energy of $284.6 \mathrm{eV}$.

Generally ${ }^{46}, \Delta G_{a d s}^{0}$ values of up to $-20 \mathrm{KJ} \cdot \mathrm{mol}^{-1}$ are consistent with the physical adsorption, while those more negative than $-40 \mathrm{KJ} \cdot \mathrm{mol}^{-1}$ involve charge sharing or transfer from inhibitor molecules to metal, i.e. chemisorption. The calculated $\Delta G_{a d s}^{0}$ equals to $-40.64 \mathrm{KJ} \cdot \mathrm{mol}^{-1}$ at $60^{\circ} \mathrm{C}$, therefore the BTAH is chemisorbed onto copper surface.

Figure 3 shows the XPS spectra of $\mathrm{CuBTA}$ and $\mathrm{Cu}$ surface. The presence of $[\mathrm{Cu}(\mathrm{I}) \mathrm{BTA}]_{\mathrm{n}}$ film is confirmed by the N1s peak at a binding energy of $399.6 \mathrm{eV}$ (Fig. 3a), which matches with nitrogen bound to phenyl groups or conjugated nitrogen ${ }^{47}$. The $\mathrm{Cu} 2 \mathrm{p}$ peak at $932.2 \mathrm{eV}$ (Fig. $3 \mathrm{~b}$ ) is attributed to the $\mathrm{Cu}$ and $\mathrm{Cu}_{2} \mathrm{O}$ that is hardly distinguished by $0.1 \mathrm{eV}$ binding energy shift ${ }^{48}$. Based on the binding energies of $\mathrm{Cu} 2 \mathrm{p}_{3 / 2}$ peak components ${ }^{49}$, no $\mathrm{CuO}$ is detected when $\mathrm{Cu}$ is not pretreated with BTAH. Whereas, on CuBTA, a second component is detected on the $\mathrm{Cu} 2 \mathrm{p}_{3 / 2}$ peak spectra at a binding energy of $934.7 \mathrm{eV}$, which originates from $[\mathrm{Cu}(\mathrm{I}) \mathrm{BTA}]_{\mathrm{n}}$ film ${ }^{50}$.

The formation of $\mathrm{Cu}-\mathrm{N}$ bond can also be confirmed by the FTIR analysis of copper surface on CuBTA after 100 min's corrosion (Fig. 4). Generally, the peaks located in $520-570 \mathrm{~cm}^{-1}$ have been attributed to the stretching vibration of $\mathrm{Cu}-\mathrm{N}$ bond ${ }^{51,52}$, therefore, the obvious peak emerged at $520 \mathrm{~cm}^{-1}$ on CuBTA indicates that BTAH has been successfully chemisorbed onto $\mathrm{Cu}$ substrate via the formation of $\mathrm{Cu}-\mathrm{N}$ atom bond.

Corrosion behavior under TELs. Figure 5 shows the Tafel curves of CuBTA and Cu under various thickness of TEL, respectively. According to Stern-Geary equation ${ }^{53}$, the corrosion current $\left(I_{\text {corr }}\right)$ that is also simply represented as the corrosion rate can be calculated,

$$
I_{\text {corr }}=\frac{B}{R_{\mathrm{p}}}=\frac{b_{a} b_{c}}{2.3\left(b_{a}+b_{c}\right)} \cdot \frac{1}{R_{\mathrm{p}}}
$$

where $R_{\mathrm{p}}$ is the so-called polarization resistance, $b_{\mathrm{a}}$ and $b_{\mathrm{c}}$ are the anodic and cathodic Tafel slopes, respectively. Therefore, $R_{\mathrm{p}}, I_{\text {corr }}$ and other parameters are listed in Table 1 .

The result that $b_{\mathrm{a}}<b_{\mathrm{c}}$ for the $\mathrm{Cu}$ (Table 1) implies the anodic branch is steeper than the cathodic branch, which indicates that the cathodic process plays more important role in copper corrosion reaction ${ }^{54}$, and also supports the reported viewpoint that the metal atmospheric corrosion process is controlled by cathodic process when the TEL thickness falls in the range of $1 \mu \mathrm{m} \sim 1 \mathrm{~mm}^{55,56}$. However, due to the protective effect of BTAH, $b_{\mathrm{a}}>b_{\mathrm{c}}$ for 


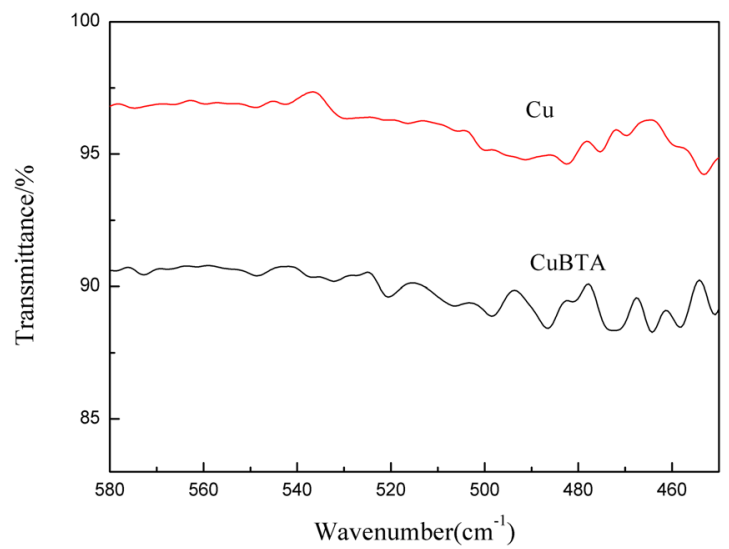

Figure 4. FTIR spectra of CuBTA and Cu after 100 min's corrosion under $100 \mu \mathrm{m}$ TEL of $3.5 \mathrm{wt} . \% \mathrm{NaCl}$. The peak located in $520 \mathrm{~cm}^{-1}$ has been attributed to the stretching vibration of $\mathrm{Cu}-\mathrm{N}$ bond.
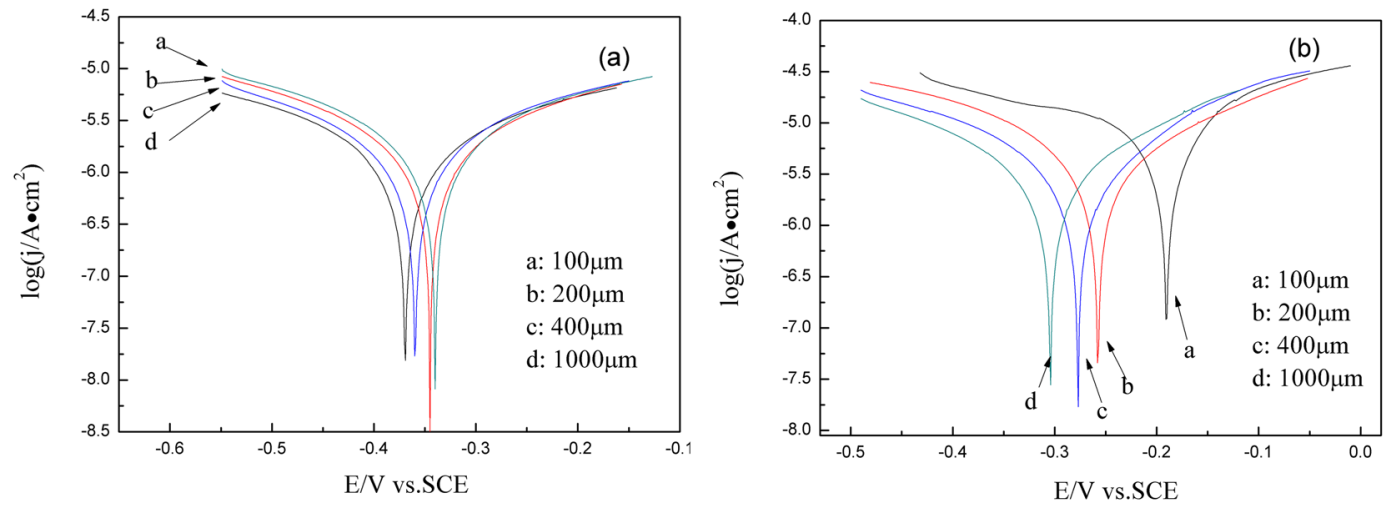

Figure 5. Tafel polarization curves of (a) $\mathrm{Cu}$ and (b) CuBTA under various thickness of TELs of $3.5 \mathrm{wt} . \% \mathrm{NaCl}$ at a scan rate of $1 \mathrm{mV} / \mathrm{s}$.

\begin{tabular}{|l|l|l|l|l|l|}
\hline & Thickness/ $/ \mathbf{m}$ & $\boldsymbol{R}_{\mathbf{p}} / \mathbf{\Omega} \cdot \mathbf{c m}^{2}$ & $\boldsymbol{b}_{\mathbf{a}} / \mathbf{m V} \cdot \mathbf{d e c}^{-\mathbf{1}}$ & $\boldsymbol{b}_{\mathbf{c}} / \mathbf{m V} \cdot \mathbf{d e c}^{-1}$ & $\boldsymbol{I}_{\text {corr }} / \boldsymbol{\mu A} \cdot \mathbf{c m}^{-\mathbf{2}}$ \\
\hline \multirow{4}{*}{$\mathrm{Cu}$} & 100 & 1646 & 222.5 & -353.7 & 36.08 \\
\cline { 2 - 6 } & 200 & 1875 & 215.1 & -221.5 & 25.30 \\
\cline { 2 - 6 } & 400 & 2616.5 & 177.0 & -196.1 & 15.46 \\
\cline { 2 - 6 } & 1000 & 2839 & 183.2 & -195.5 & 14.48 \\
\hline \multirow{4}{*}{ CuBTA } & 100 & 5984 & 211.3 & -214.2 & 7.530 \\
\cline { 2 - 6 } & 200 & 6153 & 214.5 & -198.0 & 7.376 \\
\cline { 2 - 6 } & 400 & 6405 & 205.4 & -202.6 & 7.124 \\
\cline { 2 - 6 } & 1000 & 6731 & 214.0 & -200.0 & 7.078 \\
\hline
\end{tabular}

Table 1. Corrosion current densities and Tafel slopes at different thickness electrolyte.

CuBTA except the singular point when TEL thickness is $100 \mu \mathrm{m}$ (Table 1). Whilst, both the corrosion currents of $\mathrm{Cu}$ and $\mathrm{CuBTA}$ increase with the decrease of TEL thickness (Table 1), which should be attributed to the higher transfer rate of oxygen across the thinner TEL film and its resulted acceleration on the cathodic reaction ${ }^{56}$.

Figures 6 and 7 show the EIS plots of $\mathrm{Cu}$ and CuBTA under TEL at different thickness, respectively.

The proposal models should be based on the reaction mechanism for analyzation. The proposed reactions equations (1) and (2) steps are electrochemical process, while equation (3) is a chemical process. The rate constants of the elementary steps $\left(k_{1}, k_{-1}\right.$ and $\left.k_{2}\right)$ obey the Tafel laws:

$$
\begin{gathered}
k_{i}=A_{i} \exp \left(b_{i} E\right)(i= \pm 1,2) \\
b_{i}=n F / 2 R T
\end{gathered}
$$



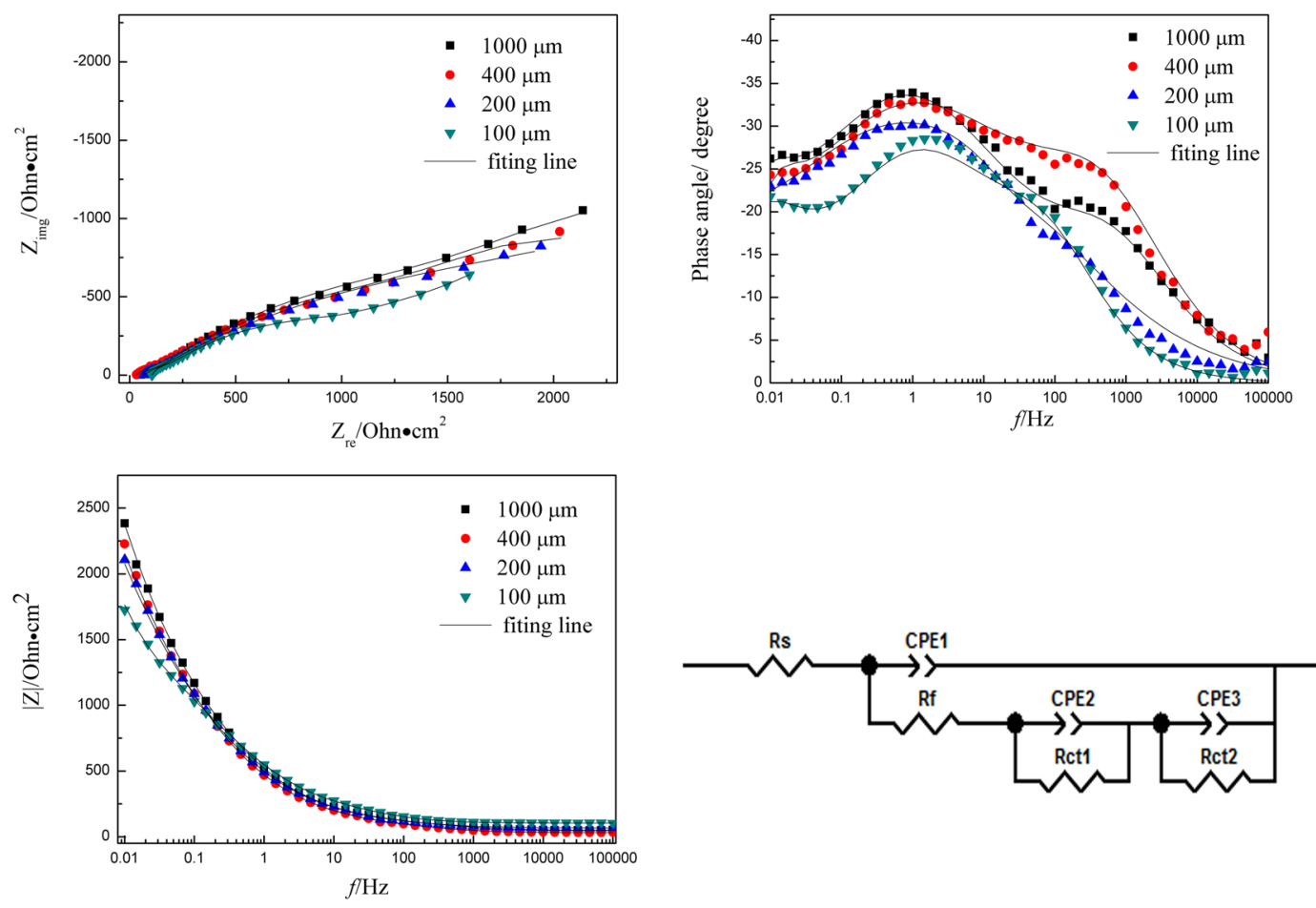

Figure 6. EIS plots of $\mathrm{Cu}$ under different thickness of TELs and corresponding equivalent circuit model. Symbols are experimental data and lines are simulated data using the equivalent circuit.
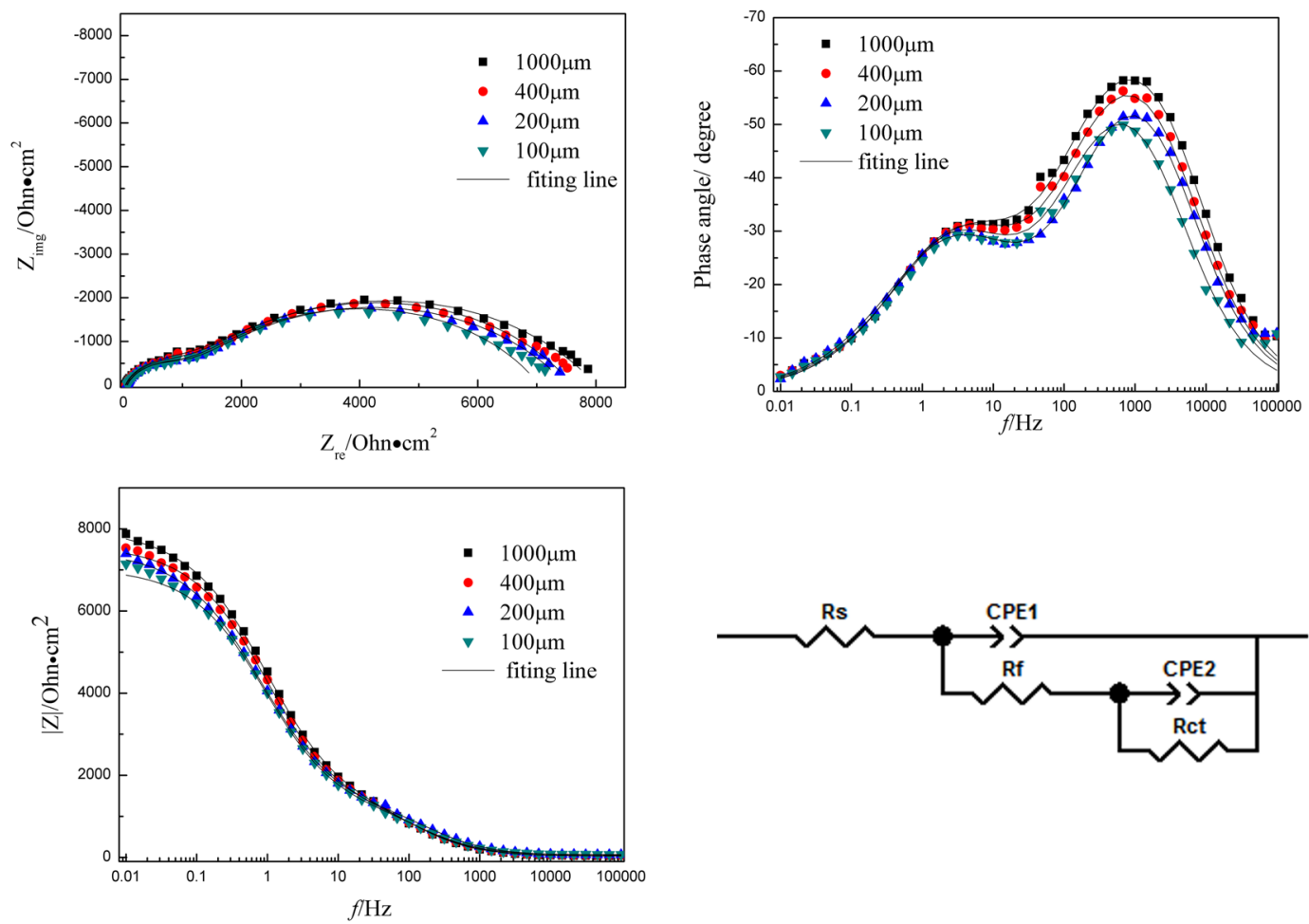

Figure 7. EIS plots of CuBTA under different thickness of TELs and corresponding equivalent circuit model. Symbols are experimental data and lines are simulated data using the equivalent circuit.

where $A_{\mathrm{i}}$ is the potential-independent pre-exponential rate constant, $E$ is overpotential and $n$ is the number of electrons involved in the reaction, $k_{\mathrm{i}}$ is the rate constant. While the rate constant $k$ of step 3 is independent of potential. 
Here present theoretical considerations for the elucidation of physical models for EIS of the corrosion process. When small ac perturbation signals are applied to a system, the Faradaic current, $I_{\mathrm{F}}$ the adatom coverage, $\theta_{\mathrm{i}}$,

$$
\Delta I_{F}=\left(\frac{\partial I_{F}}{\partial E}\right)_{s s} \Delta E+\sum_{i=1}^{n}\left(\frac{\partial I_{F}}{\partial \theta_{i}}\right)_{s s} \Delta \theta_{i}
$$

The subscript "ss" represent steady state. In which, $\Delta E=E-E_{s s}, \Delta \theta_{i}=\theta_{i}-\left(\theta_{i}\right)_{s s}, i=1,2, \ldots n$. The $\Delta$ corresponds to parameters which oscillate during ac probing.

The whole impedance of the electrode is based on these reactions, the impedance of the whole system:

$$
\begin{gathered}
Z=R_{s}+\frac{1}{Y_{F}+j \omega C_{d l}} \\
Y_{F}=\Delta I_{F} / \Delta E
\end{gathered}
$$

in which, $R_{\mathrm{s}}$ is solution resistance, $\mathrm{Cdl}$ is double-layer capacitance (in equivalent circuit model map, we use CPE1 to stand for it), and $Y_{\mathrm{F}}$ is Faraday admittance ${ }^{57}$, combined with equations (12) and (14), the expression should be:

$$
Y_{F}=1 / R_{f}+\sum_{k=1}^{n} B_{k} /\left(a_{k}+j \omega\right)
$$

In which, $l$ stands for the state variable except $E$,

$$
\begin{gathered}
a_{i, l}=-\left(\frac{\partial \epsilon_{i}}{\partial \theta_{l}}\right)_{s s} i, l=1,2, \ldots, n \\
B_{l}=\sum_{i=1}^{n} m_{i, l} \cdot b_{l} i, l=1,2, \ldots, n \\
m_{i, l}=\left(\frac{\partial I_{F i}}{\partial \theta_{l}}\right)_{s s} i, l=1,2, \ldots, n \\
b_{l}=\left(\frac{\partial \epsilon_{l}}{\partial E}\right)_{s s} \\
\epsilon_{l}=\frac{\mathrm{d} \theta_{l}}{\mathrm{~d} t}
\end{gathered}
$$

However, there are two state variable $(\mathrm{n}=2)$ without $\mathrm{BTAH}$ : the coverage rate of $\mathrm{CuCl}$ and $\mathrm{Cu}_{2} \mathrm{O}$, which presented as $\theta_{1}$ and $\theta_{2}$ respectively. Then the $\mathrm{Cu}$ should be $1-\theta_{1}-\theta_{2}$.

Then, faradic current density of the whole reaction is:

$$
I_{F}=I_{a}+I_{c}=I_{1}-I_{-1}-I_{2}=k_{1}\left(1-\theta_{1}-\theta_{2}\right) \alpha_{C l^{-}}-k_{-1} \theta_{1}-k_{2} \theta_{2} \alpha_{O_{2}}^{1 / 4}
$$

in equation (21), $\alpha$ stand for the corresponding ionic activity.

The value of $\theta_{1}$ should be increased by the positive reaction of equation (1), but equation (1) reverse reaction and equation (3) should decrease it; $\theta_{2}$ will be increased by equation (3).

At steady state,

$$
(\dot{\theta})_{s s}=k_{1}\left(1-\theta_{1}-\theta_{2}\right) \alpha_{C l^{-}}-k_{-1} \theta_{1}-k_{3} \theta_{1} \alpha_{O H^{-}}=0
$$

$k_{1}$ is rate determine step without $\mathrm{BTAH}^{58}$, the relation between $\theta_{1}, \theta_{2}$ and $t$ should be expressed by:

$$
\begin{gathered}
\epsilon_{1}=\frac{\mathrm{d} \theta_{1}}{\mathrm{~d} t}=K\left(k_{1}\left(1-\theta_{1}-\theta_{2}\right) \alpha_{C l^{-}}-k_{-1} \theta_{1}-k_{3} \theta_{1} \alpha_{O H^{-}}\right) \\
\epsilon_{2}=\frac{\mathrm{d} \theta_{2}}{\mathrm{~d} t}=K\left(k_{1}\left(1-\theta_{1}-\theta_{2}\right) \alpha_{C l^{-}}\right)
\end{gathered}
$$

in which $K$ is relative coefficient, $\epsilon_{2}$ related to the corrosion rate, which limited by $k_{1}$.

$$
m_{1,1}=\left(\frac{\partial I_{F 1}}{\partial \theta_{1}}\right)_{s s}=-k_{1} \alpha_{C l^{-}}-k_{-1}<0
$$




$$
\begin{gathered}
m_{1,2}=\left(\frac{\partial I_{F 1}}{\partial \theta_{2}}\right)_{s s}=-k_{1} \alpha_{C l^{-}}<0 \\
m_{2,1}=\left(\frac{\partial I_{F 2}}{\partial \theta_{1}}\right)_{s s}=0 \\
m_{2,2}=\left(\frac{\partial I_{F 2}}{\partial \theta_{2}}\right)_{s s}=-k_{2} \theta_{2} \alpha_{O_{2}}^{1 / 4}<0
\end{gathered}
$$

According to equation (10), $k_{1}$ and $k_{-1}$ are dependent on $E$, but $k_{3}$ is independent to $E$, combined with equations (19) and (23):

$$
\begin{gathered}
b_{1}=\left(\frac{\partial \epsilon_{1}}{\partial E}\right)_{s s}=\frac{K F}{2 R T}\left[k_{1}\left(1-\theta_{1}-\theta_{2}\right) \alpha_{C l^{-}}-k_{-1} \theta_{1}\right]>0 \\
b_{2}=\left(\frac{\partial \epsilon_{2}}{\partial E}\right)_{s s}=\frac{K F}{2 R T}\left[k_{1}\left(1-\theta_{1}-\theta_{2}\right) \alpha_{C l^{-}}\right]>0 \\
B_{1}=m_{1,1} \cdot b_{1}+m_{1,2} \cdot b_{1}<0 \\
B_{2}=m_{2,1} \cdot b_{2}+m_{2,2} \cdot b_{2}<0
\end{gathered}
$$

while,

$$
Y_{F}=\frac{1}{R_{f}}-\frac{\left|B_{1}\right|}{a_{1}+j \omega}-\frac{\left|B_{2}\right|}{a_{2}+j \omega}
$$

In this case, the equivalent circuit of the corrosion process is $\operatorname{Rs}(\mathrm{CPEl}(\mathrm{Rf}(\mathrm{Rct} 1 \mathrm{CPE} 2)(\mathrm{Rct} 2 \mathrm{CPE} 3))$, which indicate three capacitive arcs will be displayed on the impedance plane.

After pretreated with BTAH, $[\mathrm{Cu}(\mathrm{I}) \mathrm{BTA}]_{\mathrm{n}}$ film takes a function of surface, supposed as $\theta_{3}$, the covering density of intermediate $\mathrm{CuCl}$ and $\mathrm{Cu}_{2} \mathrm{O}$ will be $\theta_{1}{ }^{\prime}$ and $\theta_{2}{ }^{\prime}$ respectively $\left(\theta_{3} \gg \theta_{1}{ }^{\prime}\right)$. After ultrasonic cleaning process, $\theta_{3}$ is a constant and independent to $\Delta t$ or $\Delta E$. In consideration of excellent corrosion protection, equation (3) is restrained, $k_{3} \rightarrow 0 . \epsilon_{2}^{\prime}=\mathrm{d} \theta_{2}{ }_{2} / \mathrm{d} t=0$, Then Faraday anodic reaction has two time constants: $E$ and $\theta_{1}{ }^{\prime}$, and cathodic reaction has only one time constants: $E$. the Faraday admittance in equation (15) will be:

$$
Y_{F}=\frac{1}{R_{f}}+\frac{B^{\prime}}{a^{\prime}+j \omega T}
$$

in which,

$$
\begin{gathered}
b^{\prime}=\left(\frac{\partial \in_{1}^{\prime}}{\partial E}\right)_{s s}=\frac{K F}{2 R T}\left[k_{1}\left(1-\theta_{1}-\theta_{2}\right) \alpha_{C l^{-}}-k_{-1} \theta_{1}\right]>0 \\
m^{\prime}=\left(\frac{\partial I_{F}}{\partial \theta_{1}^{\prime}}\right)_{s s}=-K_{1}\left(1-\theta_{3}\right) \alpha_{C l^{-}}-K_{-1} \theta_{3}<0 \\
B^{\prime}=m^{\prime} \cdot b^{\prime}<0
\end{gathered}
$$

Then, $\mathrm{Y}_{\mathrm{F}}$ will be transferred into:

$$
\begin{gathered}
Y_{F}=\frac{1}{R_{f}}-\frac{\left|B_{1}\right|}{a+j \omega}=\frac{a+j \omega-R_{f}\left|B_{1}\right|}{R_{f}(a+j \omega)} \\
Z_{F}=\frac{1}{Y_{F}}=R_{f}+\frac{\frac{R_{f}^{2}\left|B_{1}\right|}{a-R_{f}\left|B_{1}\right|}}{1+j \omega \frac{1}{a-R_{f}\left|B_{1}\right|}}
\end{gathered}
$$

in this way, we suggest: 


\begin{tabular}{|l|l|l|l|l|}
\hline Thickness $/ \mu \mathrm{m}$ & $\mathbf{1 0 0 0}$ & $\mathbf{4 0 0}$ & $\mathbf{2 0 0}$ & $\mathbf{1 0 0}$ \\
\hline$R_{\mathrm{s}} / \Omega \cdot \mathrm{cm}^{2}$ & 47.5 & 31.6 & 66.4 & 104.3 \\
\hline$C P E_{1} / \mathrm{F} \cdot \mathrm{cm}^{2}$ & $5.69 \mathrm{E}-05$ & $6.85 \mathrm{E}-05$ & $7.47 \mathrm{E}-05$ & $10.0 \mathrm{E}-05$ \\
\hline $\mathrm{n}_{1}$ & 0.692 & 0.720 & 0.719 & 0.745 \\
\hline$R_{\mathrm{f}} / \Omega \cdot \mathrm{cm}^{2}$ & 77.2 & 73.6 & 51.4 & 152 \\
\hline$C P E_{2} / \mathrm{F} \cdot \mathrm{cm}^{2}$ & $7.6 \mathrm{E}-04$ & $8.8 \mathrm{E}-04$ & $8.2 \mathrm{E}-04$ & $7.0 \mathrm{E}-04$ \\
\hline $\mathrm{n}_{2}$ & 0.512 & 0.482 & 0.466 & 0.545 \\
\hline$R_{\mathrm{ct}} / \Omega \cdot \mathrm{cm}^{2}$ & 1428 & 1734 & 1643 & 1195 \\
\hline$C P E_{3} / \mathrm{F} \cdot \mathrm{cm}^{2}$ & $4.25 \mathrm{E}-03$ & $5.79 \mathrm{E}-03$ & $6.41 \mathrm{E}-03$ & $1.43 \mathrm{E}-03$ \\
\hline $\mathrm{n}_{3}$ & 0.702 & 0.678 & 0.702 & 0.859 \\
\hline$R_{\mathrm{ct} 2} / \Omega \cdot \mathrm{cm}^{2}$ & 2763 & 2322 & 1874 & 1453 \\
\hline
\end{tabular}

Table 2. Fitting results of EIS for $\mathrm{Cu}$ at different thickness of TEL.

\begin{tabular}{|l|l|l|l|l|}
\hline Thickness $/ \mu \mathbf{m}$ & 1000 & 400 & 200 & 100 \\
\hline$R_{\mathrm{s}} / \Omega \cdot \mathrm{cm}^{2}$ & 32.5 & 42.7 & 59.3 & 67.8 \\
\hline$C P E_{1} / \mathrm{F} \cdot \mathrm{cm}^{2}$ & $4.09 \mathrm{E}-06$ & $3.88 \mathrm{E}-06$ & $3.24 \mathrm{E}-06$ & $4 \mathrm{E}-06$ \\
\hline $\mathrm{n}_{1}$ & 0.819 & 0.817 & 0.810 & 0.810 \\
\hline$R_{\mathrm{f}} / \Omega \cdot \mathrm{cm}^{2}$ & 1416 & 1312 & 1220 & 1235 \\
\hline$C P E_{2} / \mathrm{F} \cdot \mathrm{cm}^{2}$ & $5.35 \mathrm{E}-05$ & $5.67 \mathrm{E}-05$ & $6.38 \mathrm{E}-05$ & $6.05 \mathrm{E}-05$ \\
\hline $\mathrm{n}_{2}$ & 0.653 & 0.649 & 0.643 & 0.665 \\
\hline$R_{\mathrm{ct}} / \Omega \cdot \mathrm{cm}^{2}$ & 6370 & 6183 & 5980 & 5720 \\
\hline
\end{tabular}

Table 3. Fitting results of EIS for CuBTA at different thickness of TEL.

$$
\begin{gathered}
R_{a}=\frac{R_{f}^{2}\left|B_{1}\right|}{a-R_{f}\left|B_{1}\right|} \\
C_{a}=\frac{1}{R_{f}^{2}\left|B_{1}\right|}
\end{gathered}
$$

then:

$$
Z_{F}=\frac{1}{Y_{F}}=R_{f}+\frac{R_{a}}{1+j \omega R_{a} C_{a}}
$$

In this case, the equivalent circuit of the corrosion process is $\operatorname{Rs}(\operatorname{CPEl}(\operatorname{Rf}(\operatorname{RctCPE} 2)))$, which indicate two capacitive arcs will be displayed on the impedance plane.

Some typical fitting parameters obtained from equivalent circuits of $\mathrm{Cu}$ and $\mathrm{CuBTA}$ are listed in Tables 2 and 3. The presence of CPE has been explained by dispersion effects that caused by microscopic roughness of the substrate surface, and $n$ is the frequency independent parameters of CPE. The decrease of CPE indicate the replacement of water on copper surface by $[\mathrm{Cu}(\mathrm{I}) \mathrm{BTA}]_{\mathrm{n}}$ film. On CuBTA, the $n_{1}$ parameter (in Table 3 ) remains approximate quantitative value $(0.80 \sim 0.82)$ at each thickness of TEL, which suggests the decreasing dispersion effects, and each corresponding morphology feature is supposed to be smooth and uniform.

In the current study, $R_{\mathrm{ct}}$, which represent corrosion resistance, could also use to estimate the corrosion rate by its inverse proportion relation. The values listed in Tables 2 and 3 verify that copper corrosion rate during its initial stage arranged in the sequence of $100 \mu \mathrm{m}>200 \mu \mathrm{m}>400 \mu \mathrm{m}>1000 \mu \mathrm{m}$, which shows good agreement with Tafel results in Table 1.

In some lectures ${ }^{59,60}$, the formation of copper oxide film under the $[\mathrm{Cu}(\mathrm{I}) \mathrm{BTA}]_{\mathrm{n}}$ film has been suggested in chloride-containing electrolyte, and in CuBTA, the $\mathrm{Cu}_{2} \mathrm{O}$ layer shows a low p-type conductivity, i.e. it becomes almost an intrinsic semiconductor, that could explain the enlargement of charge transfer resistance $\left(R_{\mathrm{ct}}\right)$ in Table 3.

Electrochemical noise analysis. The EN technique has carried out to test $\mathrm{Cu}$ and CuBTA, for the purpose to qualitatively analyze the relationship between the EN features and the corrosion severity, and the results are shown in Fig. 8. The potential curves recorded in Fig. 8 are characterized by smoothness, which is generated by the steady diffusion-controlled process ${ }^{61}$.

Fast Wavelet Transformation (FWT) technique of the fourth order is used to achieve the energy distribution plot (EDP), which theoretical algorithm is depicted in details in Fig. 9. Briefly, the real time signal sets $S_{\mathrm{n}}(\mathrm{t})(\mathrm{n}=1,2, \ldots N)$ is decomposed into two sets of coefficients: a smooth coefficient set, $S=\left(S_{1}, S_{2}, \ldots, S_{\mathrm{T}}\right)$, which 

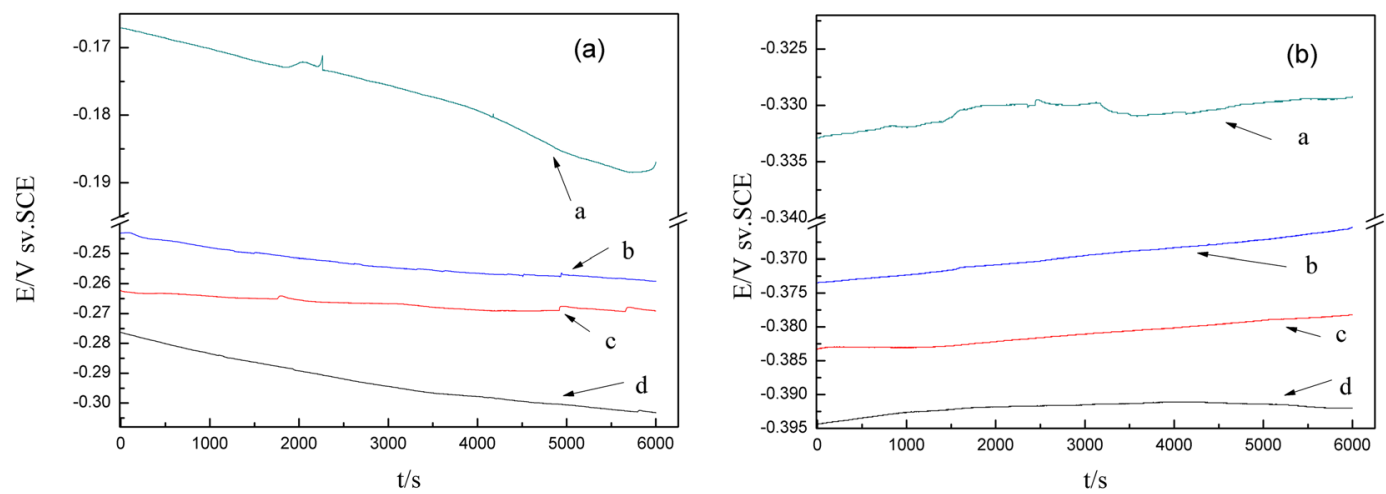

Figure 8. Electrochemical noise data of (a) Cu and (b) CuBTA under different thickness of TELs of 3.5 wt.\% $\mathrm{NaCl}$ at $20^{\circ} \mathrm{C}: \mathrm{a}-100 \mu \mathrm{m} ; \mathrm{b}-200 \mu \mathrm{m} ; \mathrm{c}-400 \mu \mathrm{m} ; \mathrm{d}-1000 \mu \mathrm{m}$. The sampling interval was $0.25 \mathrm{~s}$.

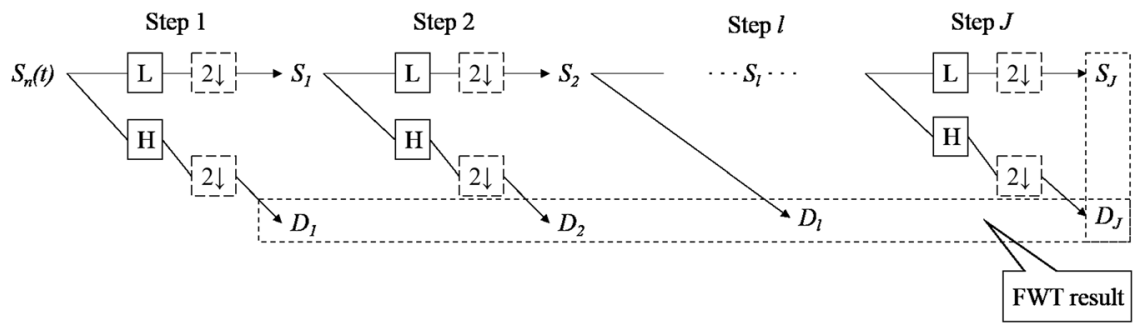

Figure 9. Theoretical algorithm scheme of the fast wavelet transform. $\mathrm{J}=8$ is often chosen for electrochemical noise experiment.

contains the information about the general trend of the signal; a detail coefficient set, $D=\left(D_{1}, D_{2}, \ldots, D_{\mathrm{J}}\right)$, which contain the information about the local fluctuations in the signal ${ }^{62}$. In FWT analyzes, $D_{1}, D_{2} \ldots D_{\mathrm{J}}$ and $S_{\mathrm{J}}$ are designated as the so-called "crystals".

Based on electrochemical noise energy $\left(E_{\mathrm{N}}\right)$ calculated, the general relations could be obtained:

$$
\begin{gathered}
E_{j}^{D}=\sum_{k=1}^{N / 2^{j}} D_{j, k}^{2},(j=1,2, \ldots, J) \\
E_{J}^{S}=\sum_{k=1}^{N / 2^{j}} S_{J, k}^{2},(j=1,2, \ldots, J) \\
E_{N}=\sum_{j=1}^{J} E_{j}^{D}+E_{J}^{S}
\end{gathered}
$$

As previous report ${ }^{36,41,63}, J=8$ is often chosen for study, and EDP map was often replotted by discounting the contribution of $S_{8}$ coefficients to the overall ensemble signal energy. The replotted EDP (RP-EDP) map can be divided into three segments, thus, the distinct type of events of electrochemical noise can be distinguished by their different time constant: (1) region I between $D_{1}$ and $D_{3}$ in the higher frequency mainly characterizes a reasonably fast phenomenon, such as metastable pitting and nucleation process, (2) region II between $D_{4}$ and $D_{6}$ mainly characterizes the growth process, and (3) region III between $D_{7}$ and $D_{8}$ at lower frequency mainly reflects the information about the diffusion process, and it has also been verified by other literatures ${ }^{64,65}$. In this paper, the RP-EDP maps without normalization at different thickness of TELs are replotted in Fig. 10, which indicate significantly large low-frequency contribution, i.e. presence of large timescale processes.

Therefore, the energy sum of $D_{1}-D_{6}\left(E_{c}\right.$, in the unit of $\left.\mathrm{V}^{2}\right)$, which is defined as the active energy of corrosion reactions, should reflect the metastable pitting nucleation and growth energy, i.e. the corrosion severity.

$$
E_{c}=E_{1}^{D}+E_{2}^{D}+E_{3}^{D}+E_{4}^{D}+E_{5}^{D}+E_{6}^{D}
$$

It should be noticed that, the general trend of the signal takes most fraction energy of tested noise. The $E_{\mathrm{c}}$ represent the energy sum of flicker noise caused by nucleation and growth of corrosion pits at a particular testing frequency ${ }^{66}$. 

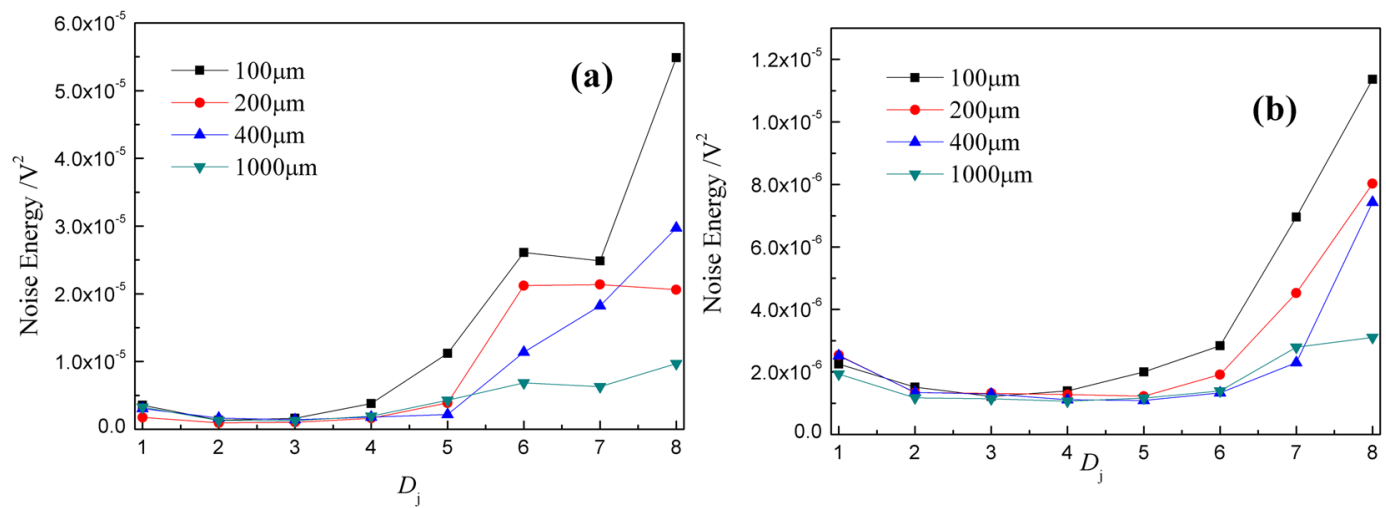

Figure 10. RP-EDP map at different thickness of 3.5 wt. $\% \mathrm{NaCl}$ thin electrolyte film: (a) $\mathrm{Cu}$ and (b) CuBTA.
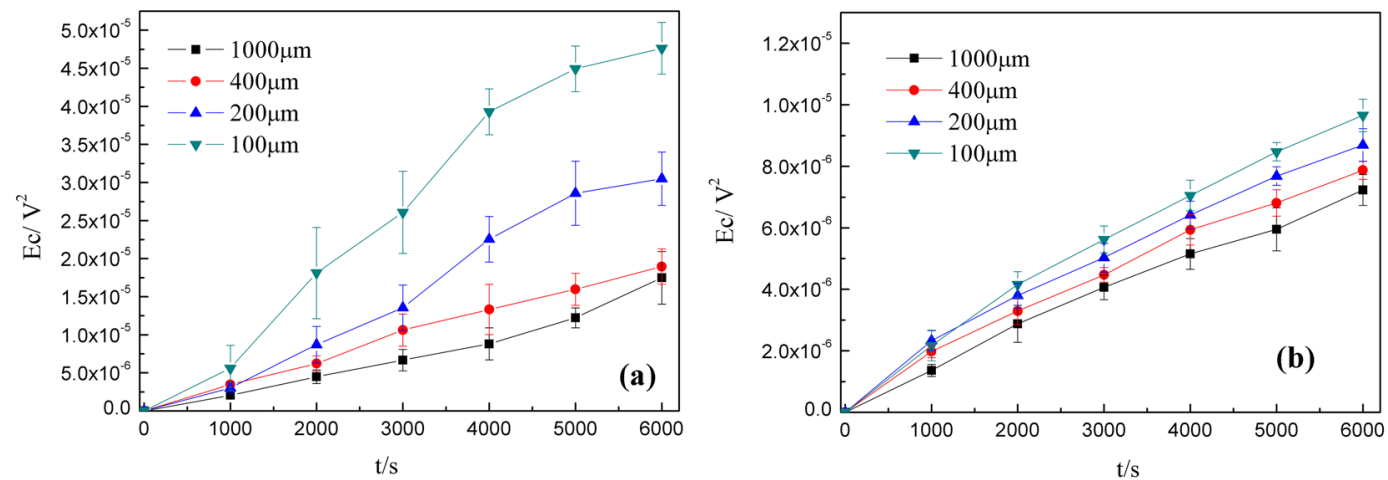

Figure 11. The relationship between corrosion energy $\left(E_{c}\right)$ and time at different thickness of thin electrolyte film: (a) $\mathrm{Cu}$ and (b) CuBTA.

\begin{tabular}{|l|l|l|l|l|}
\hline \multirow{2}{*}{ Thickness $/ \boldsymbol{\mu} \mathbf{m}$} & \multicolumn{4}{|l|}{ Average $E_{\mathrm{c}}$ density value $\left(\mathbf{d} E_{\mathrm{c}} / \mathbf{d t}\right) / \mathrm{V}^{2} \cdot \mathbf{s}^{-\mathbf{1}}$} \\
\cline { 2 - 5 } & $\mathbf{1 0 0}$ & $\mathbf{2 0 0}$ & $\mathbf{4 0 0}$ & $\mathbf{1 0 0 0}$ \\
\hline $\mathrm{Cu}$ & $8.67 \mathrm{E}-09$ & $5.59 \mathrm{E}-09$ & $3.18 \mathrm{E}-09$ & $2.75 \mathrm{E}-09$ \\
\hline CuBTA & $1.78 \mathrm{E}-09$ & $1.41 \mathrm{E}-09$ & $1.28 \mathrm{E}-09$ & $1.25 \mathrm{E}-09$ \\
\hline
\end{tabular}

Table 4. The average $E_{\mathrm{c}}$ density value $\left(\mathrm{d} E_{\mathrm{c}} / \mathrm{dt}\right)$ at different thickness of TEL.

The tested corrosion energy variation with time under different thickness of electrolyte has listed in Fig. 11. The slope of each line in Fig. 11 is defined as energy density $\left(\mathrm{d} E_{\mathrm{c}} / \mathrm{dt}\right)$ during corrosion process, and the average values are listed in Table 4.

On the purpose to qualitatively analyze the EN energy, Fig. 12 denotes the relationship between $1 / R_{\mathrm{ct}}$ (obtained by EIS) and the average corrosion energy density value $\left(\mathrm{d} E_{\mathrm{c}} / \mathrm{d} t\right)$ at each TEL with and without pretreatment of BTAH. Apparently, the $\mathrm{d} E_{\mathrm{c}} / \mathrm{d} t$ shows the direct variation trend with $1 / R_{\mathrm{ct}}$. which denotes the corrosion rate.

This result also reveals that RP-EDP maps without normalization can not only used as fingerprint to characteristic the morphology, but also speculate the corrosion energy $E_{\mathrm{c}}$ to deduce corrosion rate properly. Comparing to the traditional parameters of corrosion rate, such as weight loss or corrosion current density, the electrochemical noise offers a nondestructive on-line monitoring progress which can be easily carried out, besides, the speculated parameter $E_{\mathrm{c}}$ demonstrates closer link to the surface microstructure and represents the corrosion rate and severity.

Surface analysis. Figure 13 shows the micrographs of $\mathrm{Cu}$ and CuBTA, and the corresponding EDS analysis results are listed in Table 5. CuBTA shows a covering layer deposits surface in Fig. 13a, which definitely related to be $[\mathrm{Cu}(\mathrm{I}) \mathrm{BTA}]_{\mathrm{n}}$ film by raised $\mathrm{C}$ and $\mathrm{N}$ element relative weight in Table 5 . The morphology of $[\mathrm{Cu}(\mathrm{I}) \mathrm{BTA}]_{\mathrm{n}}$ film seems to be smooth and it's almost entirely covering the copper surface except a few black cracks left. After 100 min's corrosion, the $\mathrm{Cl}^{-}$ion pass through the cracks on the film and attack the $\mathrm{Cu}$ substrate and a few cracks are amplified (Fig. 13b), whereas the corrosion process are inhibited by the inherent film.

$\mathrm{Cu}$ surface without corrosion is smooth and uniform in Fig. 13c, whereas, the occurred corrosion pits after corrosion (Fig. 13d) denote intensive corrosion. Besides, the Cl element remain the same value after corrosion, 

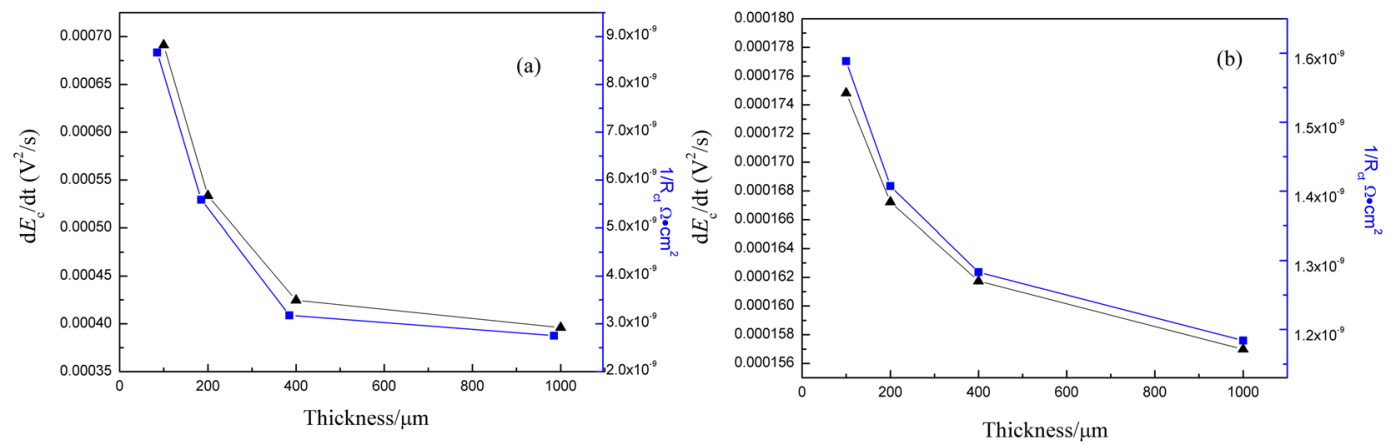

Figure 12. Relationship between $1 / R_{\mathrm{ct}}$ and average corrosion energy density $\left(\mathrm{d} E_{\mathrm{c}} / \mathrm{d} t\right)$ at different thickness of 3.5 wt.\% NaCl TELs: (a) Cu and (b) CuBTA.

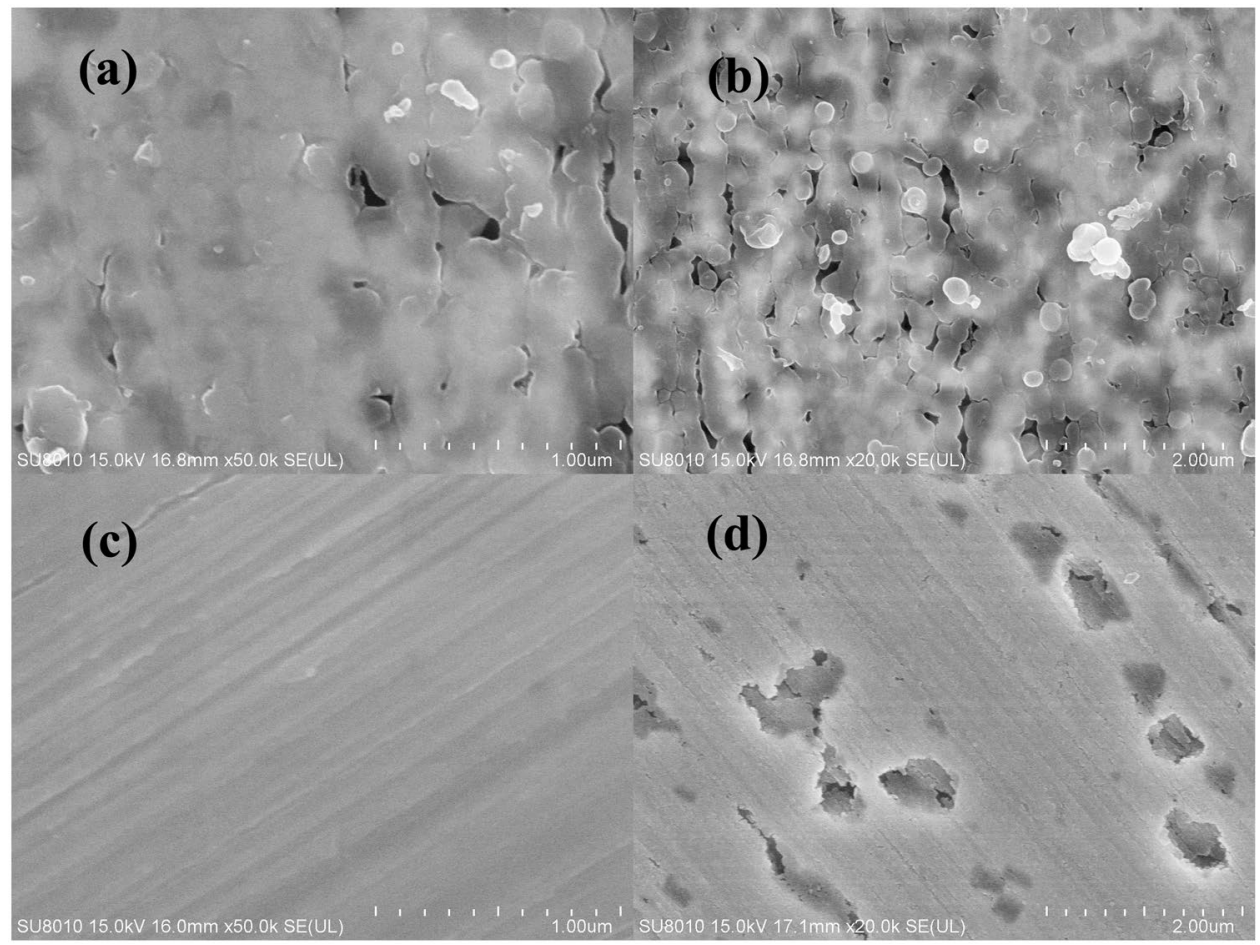

Figure 13. SEM image of samples: (a) CuBTA without corrosion, (b) CuBTA after 100 min's corrosion under $100 \mu \mathrm{m} 3.5$ wt. $\% \mathrm{NaCl}$ TEL, (c) Cu without corrosion and (d) Cu after 100 min's corrosion under $100 \mu \mathrm{m} 3.5$ wt.\% $\mathrm{NaCl}$ TEL.

\begin{tabular}{|l|l|l|l|l|l|}
\hline & $\mathbf{C}$ (wt.\%) & $\mathbf{N}$ (wt.\%) & $\mathbf{O}$ (wt.\%) & $\mathbf{C l}$ (wt.\%) & $\mathbf{C u}$ (wt.\%) \\
\hline CuBTA & 4.514 & 1.065 & 0.893 & 0.033 & 93.495 \\
\hline CuBTA after corrosion & 4.273 & 1.024 & 1.063 & 0.056 & 93.483 \\
\hline $\mathrm{Cu}$ & 0.049 & 0.076 & 1.158 & 0.076 & 98.841 \\
\hline Cu after corrosion & 0.000 & 0.047 & 1.814 & 0.070 & 98.069 \\
\hline
\end{tabular}

Table 5. Element content deduced from EDS of copper under $3.5 \mathrm{wt} \% \mathrm{NaCl}$ TEL.

hence, the main initial corrosion products of copper in chloride-containing TEL supposed to be cuprous oxide, which is accordance to other reports ${ }^{11,12,67}$.

\section{Conclusion}

The initial corrosion process of copper and the corrosion resistance mechanism of Benzotriazole (BTAH) under chloride-containing thin electrolyte layer $(3.5 \mathrm{wt} . \% \mathrm{NaCl})$ was investigated using Tafel curves, EIS, XPS and electrochemical noise measurement. The results showed that, BTAH was chemisorption onto copper surface through 
$\mathrm{Cu}-\mathrm{N}$ bond tightly, leading to $[\mathrm{Cu}(\mathrm{I}) \mathrm{BTA}]_{\mathrm{n}}$ film which had verified by theoretical calculation and experimental characterization. Corrosion rate $\left(1 / R_{\mathrm{ct}}\right)$ increased as thin electrolyte layer thickness decreases which controlled by diffusion-controlled process.

The corrosion energy $\left(E_{\mathrm{c}}\right)$ deduced from electrochemical noise served as another calculation for corrosion severity, the $E_{c}$ increased as the decreasing thin electrolyte layer thickness, and existed direct proportion to the corrosion rate $1 / R_{\mathrm{ct}}$. The correlation between $E_{\mathrm{c}}$ and corrosion rate denoted feasibility to determine corrosion rate by nondestructive on-line monitoring electrochemical noise progress.

\section{References}

1. Pan, Y.-C., Wen, Y., Xue, L.-Y., Guo, X.-Y. \& Yang, H.-F. Adsorption Behavior of Methimazole Monolayers on a Copper Surface and Its Corrosion Inhibition. J. Phys. Chem. C 116, 3532-3538 (2012).

2. Mahvash, F. et al. Corrosion resistance of monolayer hexagonal boron nitride on copper. Sci. Rep.-UK 7, 42139 (2017).

3. Zhang, X., Odnevall Wallinder, I. \& Leygraf, C. Mechanistic studies of corrosion product flaking on copper and copper-based alloys in marine environments. Corros. Sci. 85, 15-25 (2014).

4. Qiang, Y., Zhang, S., Xu, S. \& Yin, L. The effect of 5-nitroindazole as an inhibitor for the corrosion of copper in a $3.0 \% \mathrm{NaCl}$ solution. RSC Adv. 5, 63866-63873 (2015).

5. Nunez, L., Reguera, E., Corvo, F., Gonzalez, E. \& Vazquez, C. Corrosion of copper in seawater and its aerosols in a tropical island. Corros. Sci. 47, 461-484 (2005).

6. Kear, G., Barker, B. D. \& Walsh, F. C. Electrochemical corrosion of unalloyed copper in chloride media-a critical review. Corros. Sci. 46, 109-135 (2004).

7. Ferreira, J. P., Rodrigues, J. A. \& da Fonseca, I. T. E. Copper corrosion in buffered and non-buffered synthetic seawater: a comparative study. J. Solid State Electr. 8, 260-271 (2004).

8. Brossard, L. Anodic Dissolution of Copper in Concentrated LiCl Solution at pH Between 3 and 7. J. Electrochem. Soc. 130, 403-405 (1983).

9. Liu, A. et al. Theoretical and experimental studies of the corrosion inhibition effect of nitrotetrazolium blue chloride on copper in $0.1 \mathrm{M} \mathrm{H} 2 \mathrm{SO} 4$. RSC Adv. 4, 40606-40616 (2014).

10. Chen, Y. et al. Corrosion Behavior of Aluminum Bronze under Thin Electrolyte Layers Containing Artificial Seawater. Int. J. Electrochem. Sci 10, 9056-9072 (2015).

11. Mendoza, A. R., Corvo, F., Gómez, A. \& Gómez, J. Influence of the corrosion products of copper on its atmospheric corrosion kinetics in tropical climate. Corros. Sci. 46, 1189-1200 (2004).

12. Bacarella, A. \& Griess, J. The anodic dissolution of copper in flowing sodium chloride solutions between 25 and 175 C. J. Electrochem. Soc. 120, 459-465 (1973).

13. Abdullah, A. M., Al-Kharafi, F. M. \& Ateya, B. G. Intergranular corrosion of copper in the presence of benzotriazole. Scripta Mater. 54, 1673-1677 (2006).

14. Xu, Z., Lau, S. \& Bohn, P. W. The role of benzotriazole in corrosion inhibition: formation of an oriented monolayer on Cu2O. Surf. Sci. 296, 57-66 (1993).

15. Dugdale, I. \& Cotton, J. B. An electrochemical investigation on the prevention of staining of copper by benzotriazole. Corros. Sci. 3 , 69-74 (1963).

16. Cotton, J. B. \& Scholes, I. R. Benzotriazole and Related Compounds as Corrosion Inhibitors For Copper. Brit. Corros. J. 2, 1-5 (1967).

17. Lewis, G. Adsorption Isotherm for the Copper-Benzotnazole System. Brit. Corros. J. 16, 169-171 (1981).

18. Thierry, D. \& Leygraf, C. Simultaneous Raman Spectroscopy and Electrochemical Studies of Corrosion Inhibiting Molecules on Copper. J. Electrochem. Soc. 132, 1009-1014 (1985).

19. Brusic, V. et al. Copper Corrosion With and Without Inhibitors. J. Electrochem. Soc. 138, 2253-2259 (1991).

20. Poling, G. W. Reflection infra-red studies of films formed by benzotriazole on Cu. Corros. Sci. 10, 359-370 (1970).

21. Ito, M. \& Takahashi, M. IR reflection-absorption spectroscopic study of benzotriazole on copper. Surf. Sci. 158, 609-615 (1985).

22. Tromans, D. \& Sun, R. h. Anodic Polarization Behavior of Copper in Aqueous Chloride/Benzotriazole Solutions. J. Electrochem. Soc. 138, 3235-3244 (1991)

23. Huang, H., Pan, Z., Guo, X. \& Qiu, Y. Effect of an alternating electric field on the atmospheric corrosion behaviour of copper under a thin electrolyte layer. Corros. Sci. 75, 100-105 (2013).

24. Wang, H.-p et al. Corrosion behavior of 907 steel under thin electrolyte layers of artificial seawater. J. Cent. South Univ. 22, 806-814 (2015).

25. Huang, K., Wang, J., Wu, D. \& Lin, S. Copper hydroxyl sulfate as a heterogeneous catalyst for the catalytic wet peroxide oxidation of phenol. RSC Adv. 5, 8455-8462 (2015).

26. Huang, H., Dong, Z., Chen, Z. \& Guo, X. The effects of $\mathrm{Cl}-$ ion concentration and relative humidity on atmospheric corrosion behaviour of PCB-Cu under adsorbed thin electrolyte layer. Corros. Sci. 53, 1230-1236 (2011).

27. Yi, P. et al. In situ investigation of atmospheric corrosion behavior of PCB-ENIG under adsorbed thin electrolyte layer. T. Nonferr. Metal. Soc. 26, 1146-1154 (2016).

28. Hetemi, D., Combellas, C., Kanoufi, F., Pinson, J. \& Podvorica, F. I. Surface modification by electrochemical reduction of alkyldiazonium salts. Electrochem. Commun. 68, 5-9 (2016).

29. Finšgar, M. \& Kek Merl, D. An electrochemical, long-term immersion, and XPS study of 2-mercaptobenzothiazole as a copper corrosion inhibitor in chloride solution. Corros. Sci. 83, 164-175 (2014).

30. Arman, S. Y., Naderi, R. \& Markhali, B. P. Effect of DC trend removal and window functioning methods on correlation between electrochemical noise parameters and EIS data of stainless steel in an inhibited acidic solution. RSC Adv. 4, 39045-39057 (2014).

31. Motamedi, M. \& Attar, M. M. Nanostructured vanadium-based conversion treatment of mild steel substrate: formation process via noise measurement, surface analysis and anti-corrosion behavior. RSC Adv. 6, 44732-44741 (2016).

32. Rocha, P. R. F. et al. Electrochemical noise and impedance of Au electrode/electrolyte interfaces enabling extracellular detection of glioma cell populations. Sci. Rep.-UK 6, 34843 (2016).

33. Na, K.-H. \& Pyun, S.-I. Comparison of susceptibility to pitting corrosion of AA2024-T4, AA7075-T651 and AA7475-T761 aluminium alloys in neutral chloride solutions using electrochemical noise analysis. Corros. Sci. 50, 248-258 (2008).

34. Casajús, P. \& Winzer, N. Electrochemical noise analysis of the corrosion of high-purity Mg-Al alloys. Corros. Sci. 94, 316-326 (2015).

35. Du, G., Li, J., Wang, W. K., Jiang, C. \& Song, S. Z. Detection and characterization of stress-corrosion cracking on 304 stainless steel by electrochemical noise and acoustic emission techniques. Corros. Sci. 53, 2918-2926 (2011).

36. Zhang, Z., Leng, W. H., Cai, Q. Y., Cao, F. H. \& Zhang, J. Q. Study of the zinc electroplating process using electrochemical noise technique. J. Electroanal. Chem. 578, 357-367 (2005).

37. Gonçalves, W. D., Lanfredi, A. J. C. \& Crespilho, F. N. Development of Numerical Methods for Signal Smoothing and Noise Modeling in Single Wire-Based Electrochemical Biosensors. J. Phys. Chem. C 115, 16172-16179 (2011).

38. Ansari, F., Naderi, R. \& Dehghanian, C. Improvement in the corrosion resistance of stainless steel 304L in sodium chloride solution by a nanoclay incorporated silane coating. RSC Adv. 5, 706-716 (2015).

39. Bertocci, U. \& Kruger, J. Studies of passive film breakdown by detection and analysis of electrochemical noise. Surf. Sci. 101, 608-618 (1980). 
40. Guan, L. et al. Influence of aging treatment on the pitting behavior associated with the dissolution of active nanoscale $\beta$-phase precipitates for an Al-Mg alloy. Corros. Sci. 103, 255-267 (2016).

41. Cai, C. et al. Analysis of pitting corrosion behavior of pure $\mathrm{Al}$ in sodium chloride solution with the wavelet technique. J. Electroanal. Chem. 578, 143-150 (2005).

42. Rios, E. C., Zimer, A. M., Pereira, E. C. \& Mascaro, L. H. Analysis of AISI 1020 steel corrosion in seawater by coupling electrochemical noise and optical microscopy. Electrochimi. Acta 124, 211-217 (2014)

43. Dong, Z., Guo, X., Zheng, J. \& Xu, L. Calculation of noise resistance by use of the discrete wavelets transform. Electrochem. Commun. 3, 561-565 (2001)

44. Bilgic, S. \& Şahin, M. The corrosion inhibition of austenitic chromium-nickel steel in $\mathrm{H} 2 \mathrm{SO} 4$ by 2-butyn-1-ol. Mater. Chem. Phys. 70, 290-295 (2001)

45. Frumkin, A. Surface tension curves of higher fatty acids and the equation of condition of the surface layer. Z. Phys. 116, 466-484 (1925).

46. Khamis, E., Bellucci, F., Latanision, R. \& El-Ashry, E. Acid corrosion inhibition of nickel by 2-(triphenosphoranylidene) succinic anhydride. Corrosion 47, 677-686 (1991).

47. Chadwick, D. \& Hashemi, T. Adsorbed corrosion inhibitors studied by electron spectroscopy: Benzotriazole on copper and copper alloys. Corros. Sci. 18, 39-51 (1978)

48. Hayez, V., Franquet, A., Hubin, A. \& Terryn, H. XPS study of the atmospheric corrosion of copper alloys of archaeological interest. Surf. Interface Anal. 36, 876-879 (2004).

49. Chadwick, D. \& Hashemi, T. Benzotriazole adsorption on copper studied by X-ray photoelectron spectroscopy. J. Electron Spectrosc. Relat. Phenom. 10, 79-83 (1977).

50. Mansikkamäki, K., Haapanen, U., Johans, C., Kontturi, K. \& Valden, M. Adsorption of Benzotriazole on the Surface of Copper Alloys Studied by SECM and XPS. J. Electrochem. Soc. 153, B311-B318 (2006).

51. Chen, Z., Huang, L., Zhang, G., Qiu, Y. \& Guo, X. Benzotriazole as a volatile corrosion inhibitor during the early stage of copper corrosion under adsorbed thin electrolyte layers. Corros. Sci. 65, 214-222 (2012).

52. Lu, L.-P., Zhu, M.-L. \& Yang, P. Crystal structure and nuclease activity of mono(1,10-phenanthroline) copper complex. J. Inorg. Biochem. 95, 31-36 (2003).

53. Stern, M. \& Geary, A. L. Electrochemical Polarization: I. A Theoretical Analysis of the Shape of Polarization Curves. J. Electrochem. Soc. 104, 56-63 (1957).

54. Liu, W., Cao, F., Chang, L., Zhang, Z. \& Zhang, J. Effect of rare earth element Ce and La on corrosion behavior of AM60 magnesium alloy. Corros. Sci. 51, 1334-1343 (2009).

55. Tomshov, N. D. Development of the Electrochemical Theory of Metallic Corrosion. Corrosion 20, 7t-14t (1964).

56. Liao, X.-n et al. In-situ investigation of atmospheric corrosion behavior of bronze under thin electrolyte layers using electrochemical technique. T. Nonferr. Metal. Soc. 22, 1239-1249 (2012).

57. Cao, F. H., Zhang, Z., Su, J. X. \& Zhang, J. Q. Electrochemical impedance spectroscopy analysis on aluminum alloys in EXCO solution. Mater. Corros. 56, 318-324 (2005).

58. King, F., Quinn, M. J. \& Litke, C. D. Oxygen reduction on copper in neutral $\mathrm{NaCl}$ solution. J. Electroanal. Chem. 385, 45-55 (1995).

59. Modestov, A. D., Guo-Ding, Z., Hong-Hua, G. \& Loo, B. H. A study of copper electrode behavior in alkaline solutions containing benzotriazole-type inhibitors by the photocurrent response method and intensity modulated photocurrent spectroscopy. $J$. Electroanal. Chem. 375, 293-299 (1994).

60. Babić, R., Metikoš-Huković, M. \& Lončar, M. Impedance and photoelectrochemical study of surface layers on $\mathrm{Cu}$ and $\mathrm{Cu}-10 \mathrm{Ni}$ in acetate solution containing benzotriazole. Electrochimi. Acta 44, 2413-2421 (1999).

61. Zhao, B., Li, J.-H., Hu, R.-G., Du, R.-G. \& Lin, C.-J. Study on the corrosion behavior of reinforcing steel in cement mortar by electrochemical noise measurements. Electrochimi. Acta 52, 3976-3984 (2007).

62. Aballe, A., Bethencourt, M., Botana, F. J. \& Marcos, M. Wavelet transform-based analysis for electrochemical noise. Electrochem. Commun. 1, 266-270 (1999).

63. Cao, F. H., Zhang, Z., Su, J. X., Shi, Y. Y. \& Zhang, J. Q. Electrochemical noise analysis of LY12-T3 in EXCO solution by discrete wavelet transform technique. Electrochimi. Acta 51, 1359-1364 (2006).

64. Liu, X., Zhang, T., Shao, Y., Meng, G. \& Wang, F. In-situ study of the formation process of stannate conversion coatings on AZ91D magnesium alloy using electrochemical noise. Corros. Sci. 52, 892-900 (2010).

65. Aballe, A., Bethencourt, M., Botana, F. J., Marcos, M. \& Sánchez-Amaya, J. M. Use of wavelets to study electrochemical noise transients. Electrochimi. Acta 46, 2353-2361 (2001).

66. Chen, Y. et al. In-situ monitoring the inhibition effect of benzotriazole on copper corrosion by electrochemical noise technique. $J$. Taiwan Inst. Chem. E. 80, 908-914 (2017).

67. Liao, X. et al. Corrosion behaviour of copper under chloride-containing thin electrolyte layer. Corros. Sci. 53, 3289-3298 (2011).

\section{Acknowledgements}

The authors wish to acknowledge the financial supports from the National Natural Science Foundation of China (Project 51771173, 21273199, 51131005 and 21403194), the Doctoral Research Foundation of Binzhou University (2017Y01), and the Major Project of Binzhou University (2017ZDL02), Scientific Research Fund of Binzhou University (BZXYZZJJ201604) and National Training Programs of Innovation and Entrepreneurship (201710449016)

\section{Author Contributions}

C. Yi performed the measurements and wrote the manuscript. B. Zhu supervised and interpreted the research. Z. Zhang participated in writing the main manuscript text and bibliographic analysis of specific case studies. Y. Chen helped with the revise of manuscript and participated in writing the manuscript. X. Du helped with interpreted data and wrote the manuscript. Y. Yang participated in writing the manuscript. J. Liu helped with interpreted electrochemical noise data. All authors discussed the results and commented on the manuscript.

\section{Additional Information}

Supplementary information accompanies this paper at https://doi.org/10.1038/s41598-018-23927-w.

Competing Interests: The authors declare no competing interests.

Publisher's note: Springer Nature remains neutral with regard to jurisdictional claims in published maps and institutional affiliations. 
(i) Open Access This article is licensed under a Creative Commons Attribution 4.0 International License, which permits use, sharing, adaptation, distribution and reproduction in any medium or format, as long as you give appropriate credit to the original author(s) and the source, provide a link to the Creative Commons license, and indicate if changes were made. The images or other third party material in this article are included in the article's Creative Commons license, unless indicated otherwise in a credit line to the material. If material is not included in the article's Creative Commons license and your intended use is not permitted by statutory regulation or exceeds the permitted use, you will need to obtain permission directly from the copyright holder. To view a copy of this license, visit http://creativecommons.org/licenses/by/4.0/.

(C) The Author(s) 2018 